\section{A socio-historical approach to policy analysis: the case of the Brazilian Workers' Food Policy}

\author{
Uma abordagem sócio-histórica à análise de \\ políticas: o caso do Programa de Alimentação do \\ Trabalhador no Brasil
}
Un enfoque sociohistórico para el análisis de políticas: el caso de la Política Alimentaria de los Trabajadores de Brasil

Jamacy Costa-Souza 1,2

Ligia Maria Vieira-da-Silva 1

Patrice Pinell 3

\begin{abstract}
Policy analyses based on traditional or structuralist definitions of the state are important, but they have some limitations for explaining processes related to policymaking, implementation, and results. Bourdieusian sociology links the analysis to objective and subjective dimensions of social practices and can help elucidate these phenomena. This article provides such empirical evidence by analyzing the social genesis of a Brazilian policy that currently serves 18 million workers and was established by the state in 1976 through the Fiscal Incentives Program for Workers' Nutrition (PIFAT/PAT). The study linked the analysis of the trajectory of social agents involved in the policy's formulation to the historical conditions that allowed the policy to exist in the first place. Although the literature treats the policy as a workers' food program (PAT), the current study showed that it actually represented a new model for paying financial subsidies to companies that provided food to their employees, meanwhile upgrading the commercial market for collective meals. The study further showed that the program emerged as an administrative policy, but linked to economic agents. The program became a specific social space in which issues related to workers' nutrition became secondary, but useful for disguising what had been an explicit side of its genesis, namely its essentially fiscal nature.
\end{abstract}

Occupational Health Policy; Nutrition Programs; Food Services; Sociology

\author{
Correspondence \\ J. Costa-Souza \\ Av. Araújo Pinho 32, Salvador, BA 40140-320, Brasil. \\ jamacy@ufba.br \\ 1 Instituto de Saúde Coletiva, Universidade Federal da Bahia, \\ Salvador, Brasil. \\ 2 Escola de Nutrição, Universidade Federal da Bahia, \\ Salvador, Brasil. \\ 3 Centre Européen de Sociologie et de Science Politique, \\ Paris, France.
}




\section{Introduction}

Health policy studies frequently provide guidance for action and their instrumental dimension has been explicitly favoured to the detriment of sociological analysis 1,2,3, sometimes with no clear theoretical framework 4 , or disconnecting science from practice and policy making 5 . Analysing a public policy understood as a State response to a given social problem also demands an interpretation of the meaning and functioning of the State, involving the bridging of theoretical and methodological gaps.

Policy analyses usually explicitly or implicitly adopt theories that correspond to a teleological vision of the State. Those classical approaches conceive the State as a neutral place aimed at promoting universal common good and social order. According to the view expressed by structuralists, including Marxists, the State represents the interests of the dominant classes and may or may not incorporate the demands of the masses into their strategies for the reproduction of capital, workforce and, ultimately, social order. Several approaches, ranging between these two extremes, have described important policy aspects, however, many authors have indicated limitations in their explanations of the processes for policy formulation, implementation and results 6,7,8,9.

In order to bridge some of these gaps, the Bourdieusian sociology has been adopted as an approach for the study of social phenomena, since it enables integrating and coordinating the social structures and the subjectivity of the social practice 10 . Bourdieusian concepts have been incorporated into studies on social determinants of health 11,12,13 and used to develop decision-making frameworks for family doctors 14 . However, this has frequently been limited to the isolated use of certain concepts, such as capital, habitus and field 13,15,16.

Thus, the analytical potential of Bourdieu's practice theory has therefore not been fully explored in health policy studies. Exceptions may be found in certain works on related themes, such as old age 17 and addictology 18, and, more importantly, in those of Pinell 19,20. While Bourdieu studied empirically distinct social fields, Pinell analysed social spaces located in the intersection between several fields, dominated by the bureaucratic field, which for Bourdieu constitutes the State, place of the official monopoly of the legitimate use of physical and symbolic violence 21.

For Bourdieu, understanding a social phenomenon involves studying its historical construction, since it may reveal initial and potential disputes that may not materialise and, as the policy becomes institutionalised, are later forgotten. This phenomenon of "forgetfulness" and "naturalization" is what the author called genesis amnesia 21.

This paper analyses a national food policy as an exemplary case. It demonstrated that, although it was known as a state activity mainly aimed at the workers' health, the Tax Incentive Program for Workers' Food (Programa de Incentivo Fiscal à Alimentação do Trabalhador; PIFAT/PAT), instituted in 1976, was explicitly and essentially Tax Incentive Legislation for businesses. These two words (tax and food) allowed it to be characterized not only as a Workers' Food Program (PAT) 22,23,24, but also as a program for tax and food simultaneously (PIFAT/PAT), a real combination concealed by the amnesia of genesis but revealed by this investigation. In its formulation and management, it was constituted as a social space of relationships between agents from different social fields, predominantly from economics, while nutritional health professionals played a secondary role.

The policy choice was related to the fact that, on a daily basis, approximately 18 million Brazilian workers currently receive meals through this program 25 , which has expanded over the last three decades, mostly in the industrial and service sectors, and amongst workers who receive up to six minimum wages 26,27. These features have led to the following research questions: how can we explain the unusual longevity of this program, which was envisaged as temporary, but has run for more than 38 years? Can the issue of workers' food be considered a public policy incorporated into a social space, or has it come to constitute a specific space? How do the various agents coordinate in order to make it viable? What are the relationships with the field of power?

Despite variations in objects and approaches of studies reviewed, the authors have essentially dealt with the food dimension 22 , or only referred to the tax dimension as a secondary aspect, without considering its different forms $23,26,28,29,30,31$. While some works simply reproduce the content of norms and documents, uncritically accepting the official discourse 23,31 , others have explicitly or implicitly considered two conceptions of the State in their analyses: the classical view, which operates through 
PAT for the wellbeing of workers 24,32,33 and the Marxist concept, in which the State's function is to reproducte the workforce and to mitigate capital-labour conflicts 27,34 .

Considering the results of this review, one can see that the emergence of this phenomenon has been the subject of relatively little investigation and insufficient theories have even been used to explain the conditions of its social construction, development and its meaning beyond the specific issue of food.

\section{Methods}

A socio-historical study was conducted considering the period from 1975, the beginning of the drafting of the Brazilian National Food and Nutrition Program (Programa Nacional de Alimentação e Nutrição; PRONAN II), and 1978, when companies began to effectively benefit from PIFAT/PAT. Within this time interval, we identified the main disputes that led to the still dominant points of view by the end of this study.

The policy conditions of emergence were analysed from document and oral sources. An intentional sample of agents was chosen, composed of those associated with its creation and implementation (Table 1), identified in the consulted documents or suggested by key informants. Interviews not only supported the reconstruction of facts, but also made an analysis of their trajectory possible and contributed to an in-depth study of policy provisions.

Policy trajectory analysis was thus a useful methodological resource in understanding the social game and enabling us to find meaning in the positions agents assumed, analysing a series of successive positions occupied within a specific space 35 . These positions are the basis for understanding the architecture of a social microcosm studied at different moments in time. In our specific case, the agents' positions were analysed by investigating the various types of capital that were effective within the formulation dynamic: political, activist, cultural, scientific, bureaucratic and social capital.

The notion of capital in Bourdieu considers the mechanisms for social production and reproduction that go beyond economic capital. Capital, which is as connected to the notion of field as it is to that of habitus, is understood as social energy 36 , an asset that enables its holder to play according to the specific and legitimate rules of each social space. While cultural capital may exist in its incorporated, objective (such as property), or institutionalized (such as diplomas) states 37 , social capital is the product of an agent belonging to a lasting and useful network of interactions 38. Symbolic capital corresponds to the transformation of other forms of capital into recognition, and is a component of the legitimacy of domination 35. Political capital is, largely, symbolic capital, since it is a reputational asset. Although similar, the marked difference between it and activist capital regards those spaces in which each one is effective ${ }^{39}$. Bureaucratic capital is an information asset, a meta-capital that exercises power over other forms of capital and is specific to the bureaucratic field 21.

Comparisons between and amounts of the various types of capital accumulated were measured according to the properties detailed in Table 2. Indicators for the composition and classification of the various types of capital can be found in Table 3 .

Twenty-four interviews (identified by the letter E) were conducted, 21 face-to-face in-depth interviews and three structured interviews (Table 1). We experienced one loss and five refusals. We consulted documents, such as legislation, reports, booklets, reviews, articles, publicity, minutes, conference reports, journals, programs and other related bibliographical material. Tens of websites of public bodies, companies, unions and associations related to PIFAT/PAT were also consulted, besides a Google search on each agent. The sample size was defined through data saturation, using the snowball technique. Interviews were transcribed and were analysed together with the others documents, using NVivo 9 software (QRS International Pty, Doncaster, Australia).

Data was summarized in matrixes containing the following features and indicators: social and professional trajectory, and position in the respective spaces at time of genesis.

The project was approved by the Ethics Research Committee and the interviewees signed a Free and Informed Consent Form. 


\section{Table 1}

Agents interviewed.

\begin{tabular}{|c|c|}
\hline Agent & Feature \\
\hline E1 & Doctor, university professor, member of the organizing commission of the 1st National Workers' Health Conference \\
\hline E2 & Nutritionist, technical supervisor for the establishment of PIFAT/PAT within certain companies at the beginning of the program \\
\hline E3 & Sociologist, member of the team that developed the PRONAN II \\
\hline E4 & $\begin{array}{l}\text { Nutritionist, member of the working group for drafting the most recent nutrition parameters for the PIFAT/PAT and advisor to the } \\
\qquad \text { Federal Council of Nutritionists }\end{array}$ \\
\hline E5 & President of ABERC \\
\hline E6 & President of the General Workers Central of Brazil \\
\hline E7 & Nutritionist, member of the team that developed PRONAN I and II \\
\hline E8 & Manager and lawyer, President of the National Association for Companies with Meal Agreements \\
\hline E9 & Nutritionist, university professor, researcher of PIFAT/PAT and occasional consultant to the Ministry of Labor \\
\hline E10 & Graduate from the Department of Letters, PIFAT/PAT Coordinator for 24 years \\
\hline E11 & $\begin{array}{l}\text { Economist, university professor, has researched PIFAT/PAT, occasional consultant to the Ministry of Labor and the business } \\
\text { associations related to PIFAT/PAT }\end{array}$ \\
\hline E12 & Nutritionist and doctor from the Ministry of Labor, completed a master's study evaluating the impact of the PIFAT/PAT implementation \\
\hline E13 & Food engineer, university professor, member of the team that developed PRONAN II \\
\hline E14 & $\begin{array}{c}\text { Nutritionist, was Vice-President of the Federal Council of Nutritionists when working jointly with the Ministry of Labor and Employment } \\
\text { to modify the PIFAT/PAT nutrition parameters }\end{array}$ \\
\hline E15 & Accountant, was PAT Coordinator at the Ministry of Labor and Employment at the time of the interview \\
\hline E16 & Dentist and manager, was Executive Director of INAN during PRONAN II and member of the first PIFAT/PAT Commission \\
\hline E17 & $\begin{array}{l}\text { Occupational physician and university professor, was Director of the Department of Security and Health at the Ministry of Labor and } \\
\text { Employment. Researcher in workers' health }\end{array}$ \\
\hline E18 & Member of David Luiz Boianovsky's family \\
\hline E19 & Nutritionist, was a member of the working group that drafted the most recent PIFAT/PAT nutrition parameters \\
\hline E20 & Nutritionist, technical supervisor for the establishment of PIFAT/PAT within certain companies at the beginning of the program \\
\hline E21 & $\begin{array}{l}\text { Nutritionist and physical education graduate, university professor, was a key informant regarding João Bosco Rennó Salomon, who } \\
\qquad \text { worked with David Boianovsky on one of the proposals that became PIFAT/PAT }\end{array}$ \\
\hline E22 & $\begin{array}{l}\text { Veterinary doctor, university professor, was a key informant regarding João Bosco Rennó Salomon, who worked with David } \\
\qquad \text { Boianovsky on one of the proposals that became PIFAT/PAT }\end{array}$ \\
\hline E23 & Nutritionist, technical supervisor for the establishment of PAT within certain companies at the beginning of the program \\
\hline E24 & Member of Oswaldo Checchia's family \\
\hline
\end{tabular}

ABERC: Brazilian Association of Collective Meals; INAN: Brazilian National Institute for Food and Nutrition; PIFAT/PAT: Tax Incentive Program for Workers' Food; PRONAN: Brazilian National Food and Nutrition Program.

\section{Results and discussion}

\section{The social construction of the program}

This research identified that the PIFAT/PAT was set up as a specific space for coordination between agents from different fields: bureaucratic, economic and medical. However, its emergence took place within the bureaucratic field, under the leadership of the Minister of Labor, Arnaldo da Costa Prieto (Prieto), an engineer with enhanced political capital at that time, since he had also been a Federal Deputy and the National Director of the party that supported the military government at the time. Also within the Brazilian Minister of Labor, were Pediatrician David Luiz Boianovsky (Boianovsky) and Teacher Luiz Gonzaga Ferreira (Ferreira). Later, Professor of Letters and ex-Nun Eglacy Porto Silva (Silva) joined the team and was subsequently its Coordinator for 24 years.

Beyond his technical capital, Boianovsky's participation was associated with his lost position within the space for the formulation of nutrition policies under the General Geisel Government 


\section{Table 2}

Features and indicators to analyse the trajectory of agents involved in the Tax Incentive Program for Workers' Food (PIFAT/PAT) formulation.

\begin{tabular}{ll} 
Analysis & Indicator \\
\hline
\end{tabular}

Agents' position in the social space

Teachers and researchers (with specific adaptations to the Brazilian scientific field) *

Agents from the bureaucratic field

Agents from the economic field **
(1) Social trajectory departure point - based on parents' and grandparents' profession and education; (2) Position within the social space - based on professional trajectory; (3) Political disposition indicators - political party membership; occupation of administrative post arising from a specifically political coordination; and participation in elective office; (4) Activist disposition indicators - leadership of professional, business or mass movement. Director of non-governmental organization, union and association or equivalent institution.

(1) Administrative, university capital indicators: participation in directing institutions, commissions and collegiate bodies; (2) Indicators of specifically scientific capital: scientific production, citations, supervising PhDs, and awards; (3) Field position indicators: university where the person works (or worked), university where has completed PhD or post-doctoral studies, and with which maintained exchange programs and has published papers.

(1) Indicators of specifically bureaucratic capital: posts occupied; (2) Political capital indicators: occupation of administrative post leading to specifically political coordination, and participation in political parties; (3) Activist capital indicators: professional participation in health conferences, symposiums and others; leadership of professional, business or mass movement; and director of non-governmental organization, union and association, or equivalent institution; (4) Technical capital indicators: training, graduate studies and publications.

(1) Private administrative capital: related to posts occupied, the amount of resources and decisionmaking level that led to the post, such as post on administrative council, board or in management role; (2) Political capital: political party membership; occupation of administrative post leading to specifically political coordination; and participation in elective office; (3) Activist capital: leadership of professional, business or mass movement; and director of non-governmental organization, union and association, or equivalent institution.

* Adapted from Vieira-da-Silva \& Pinell 58;

** Adapted from Chiavenato 59.

(1974 to 1978), and his social capital with Prieto, which was converted into elevated bureaucratic capital. Having actively participated in setting up the Brazilian National Institute for Food and Nutrition (INAN), a body within the Brazilian Ministry of Health, during the General Médici Government (1970 to 1974), he was expected to preside over it (E18). However, the position was given to the Diplomat José Maria Diniz Ruiz de Gamboa, who had no apparent connection to health or nutrition 40. Something similar occurred in June 1974: the newspapers announced that Boianovsky was the new President of INAN 41, but he was overlooked for the second time. In September, Bertoldo Kruse Grande de Arruda, ex-State Secretary of Health, doctor and a professor at the Federal University of Pernambuco (UFPE) Institute of Nutrition, took up the position 42.

Boianovsky studied medicine at the Federal University of Rio Grande do Sul (1957) and, between 1958 and 1971, worked as a pediatrician in Criciúma (South region of Brazil), where he also carried out several other medical activities, including Hospital Management, the Planning and Administration of Child Health Programs and Corporate Representation (on the Ethics Committee of the Santa Catarina State Association of Medicine), where he came to know Silva. In 1971, he went to the University of Brasilia (UnB) in the country's capital, invited by his Neonatologist Junqueira Lisboa, because of his specialist knowledge in this area; here he joined the group run by doctor and researcher João Bosco Renó Salomon (E18).

Although conflicts at UnB influenced him, Boianovsky's departure to the Ministry of Labor seems to have come about as a result of his social capital: a friend of Prieto, also from Rio Grande do Sul State, his neighbour, member of the same club and involved in the same social events (E18). According to Boianovsky, the proposal was first communicated at Sunday lunch in the Minister's house: 
Table 3

Composition and classification of the different types of capital during the first years of the Tax Incentive Program for Workers' Food (PIFAT/PAT), 1976-1978.

\begin{tabular}{|c|c|c|c|c|}
\hline \multirow[t]{3}{*}{ Type of capital } & \multicolumn{4}{|c|}{ Amount of capital } \\
\hline & Very high & High & Medium & Low \\
\hline & $\uparrow \uparrow \uparrow \uparrow$ & $\uparrow \uparrow \uparrow$ & $\uparrow \uparrow$ & $\uparrow$ \\
\hline Bureaucratic * & $\begin{array}{l}\text { Directorship of } \\
\text { an international } \\
\text { organization; Ministry of } \\
\text { Health; Ministry of Labor }\end{array}$ & $\begin{array}{l}\text { Intermediate } \\
\text { directorship and } \\
\text { technical role at State } \\
\text { Health Departments; } \\
\text { INAN and IPEA }\end{array}$ & $\begin{array}{l}\text { Intermediate directorship } \\
\text { and technical role } \\
\text { at Municipal Health } \\
\text { Departments }\end{array}$ & $\begin{array}{l}\text { Technical post (advisor, } \\
\text { consultant) }\end{array}$ \\
\hline University bureaucratic * & Rector & Unit Director & $\begin{array}{l}\text { Head of Department; and } \\
\text { Post-graduate Coordinator }\end{array}$ & Subject Coordinator \\
\hline Private administrative ** & $\begin{array}{l}\text { Company Management } \\
\text { Board: posts related } \\
\text { to significant decision- } \\
\text { making, such as defining } \\
\text { areas of operation, } \\
\text { acquisitions, merges, } \\
\text { investments, etc. }\end{array}$ & $\begin{array}{l}\text { Executive and Director } \\
\text { post. Activities of a more } \\
\text { strategic nature }\end{array}$ & $\begin{array}{l}\text { Manager. Activities of a } \\
\text { more tactical nature }\end{array}$ & $\begin{array}{l}\text { Activities that allow for } \\
\text { the basic execution of } \\
\text { tasks }\end{array}$ \\
\hline \multicolumn{5}{|l|}{ Political * } \\
\hline $\begin{array}{l}\text { Occupation of } \\
\text { administrative post } \\
\text { leading to specifically } \\
\text { political coordination }\end{array}$ & $\begin{array}{l}\text { Minister, President of } \\
\text { Regulating Agency }\end{array}$ & $\begin{array}{l}\text { State and District } \\
\text { Secretary }\end{array}$ & Municipal Secretary & $\begin{array}{c}\text { Other politically } \\
\text { appointed technical post }\end{array}$ \\
\hline $\begin{array}{l}\text { Participation in political } \\
\text { party }\end{array}$ & National leader & State leader & Municipal leader & Member of political party \\
\hline $\begin{array}{l}\text { Participation in elective } \\
\text { office }\end{array}$ & $\begin{array}{c}\text { Senator or Federal } \\
\text { Deputy }\end{array}$ & State or District Deputy & City councillor & \\
\hline $\begin{array}{l}\text { Activist (professional, } \\
\text { business or mass } \\
\text { movement leadership) }\end{array}$ & National leader & State leader & Municipal leader & Local leader \\
\hline Scientific * & $\begin{array}{l}\text { International recognition; } \\
\text { International awards; } \\
\text { Recognition in other } \\
\text { domestic scientific } \\
\text { spaces (Academies of } \\
\text { Science) }\end{array}$ & $\begin{array}{l}\text { National recognition; } \\
\text { Tenured professor }\end{array}$ & Local recognition; PhD & Master's \\
\hline
\end{tabular}

INAN: Brazilian National Institute for Food and Nutrition; IPEA: Institute for Applied Economic Research.

* Adapted from the classification used by Vieira-da-Silva \& Pinell 58;

** Based on the classification presented by Chiavenato 59.

"I was at the Massachusetts Institute of Technology, where I was working on a program for the Institute of Nutrition of Central America and Panama [Instituto de Nutrição do Centro América e Panamá; INCAP] (...) I received a letter (...) saying that a mutual friend had been made Minister of Labor (...). At INCAP, I saw the work of (...) Leonardo Matto, concerning the energy expended by individuals carrying out various work activities and the relationship to productivity, available energy, and nutritional status (...).

I arrived here [in Brazil], and a week later I was invited to have lunch with Prieto. (...) I mentioned this idea. Why don't you set up a workers' food programme? He asked me to put it down on paper. About three weeks later, he invited me to work with him and carry it out. I didn't accept, because I wasn't interested in working with the 
government. I was a university professor and a doctor. In the end, I quarrelled with the Rector, left the university, and was invited by the Minister; I went there and we set up the PAT" 43.

This period has been described as political detente, because of initiatives by the General Geisel Government and growing pressure from the mass movements. Prieto was appointed Minister of Social Security and Labor, within the space of social policies related to labor, in charge of the 2nd National Development Plan (II Plano Nacional de Desenvolvimento; PND II) Guidelines which, amongst other things, sought to establish a policy for "the accelerated training of the workforce, increasing its income generating capacity, through education, professional training, health, sanitation and nutrition" 44 (p. 119).

Since the Ministry of Labor lacked the knowhow to formulate food interventions, the PIFAT/ PAT copied the "Programme of Tax Incentives for Workforce Training" led by Ferreira, who was linked to professional training and came from the economic and bureaucratic fields. He was connected to the National Service for Industrial Apprenticeship (SENAI) (Advertisement. Folha S. Paulo 1962; 16 jun) but had links to the Ministries of Education - through the National Staff Development Centre for Professional Training (CENAFOR) (Advertisement. Folha S. Paulo 1976; 16 jun) and Labor.

Participation of agents from the economic field is best understood in the light of the creation of associative spaces for personnel managers. In the 1960s, professionals from large companies developed an organizational strategy which resulted in the 1964 creation of the Diogenes Group, later the Brazilian Association of Personnel Management (ABAPe), and then, from 1965 onwards, the Brazilian Association of Human Resources (ABRH-Nacional). At least two of these agents played decisive roles in the formulation of PIFAT/PAT: Antônio Guimarães (Guimarães; E5) and Oswaldo Checchia (Checchia).

It has been suggested that the Diogenes Group influenced the modernization of labour relations in Brazil, with personnel managers occupying high-level posts in large companies, responsible for the planning of workers' food, medical assistance and hygiene, amongst other things 45 .

The relationship between agents from the ABAPe and Prieto were such that the minister presided over the inauguration of its headquarters in 1976 (Advertisement. O Estado de S. Paulo 1976; 27 jul) and Checchia described himself on his CV as an "ex colaborador del Ministerio de Trabajo" [ex-associate of the Ministry of Labor] (E24). This process constitutes the formation of a new social space within the economic field, product of the specialization of personnel management, within which issues related to professional training and workers' food began to be addressed. This convergence began with the 1939 Decree, when the Vargas Government (1930-1945) made it compulsory for certain companies to have their own restaurants 46 .

Although the dominant space for its creation was the Ministry of Labor, where agents predominantly acted according to trajectories within the bureaucratic field, the PIFAT/PAT space also grew out of intense coordination between agents and institutions from the economic field, through interaction and relationships between the public and the private, the bureaucratic and the economic; between the spaces for personnel managers and executives from major industries and food companies, whose potential was in line with their social capital activities and whose synthesis can be seen in the fact that Guimarães, a teacher, was part of the team that prepared the programme implementation modifications. Director of a collective meal company (Riga, created in 1968) and an ABAPe founder, he worked in Rhodia with Checcia, who invited him to participate in PIFAT/PAT audiences with Prieto, where he once again met Ferreira and was then introduced to Boianosvky:

"In 1976, I was getting to know PAT and was interested in the Program. I accompanied a great friend, the President of the ABRH, on a visit to the Minister of Labor (...). At that audience, I met Dr. Boianovsky (...). He was with Prof. Ferreira (...). I had set up a program of Programmed Instruction for Paramount with Prof. Ferreira - who was President of CENAFOR at the time - and we became friends, which facilitated my initial friendship with Dr. David, [who] invited me to participate in the regulation of Law 6321/76" (E5).

The companies provided personnel and material support to the program preparation, paying travels, accommodation and salaries. Boianovsky 43 emphasized the participation of nutritionists Akiko [Miyagui] from Philips and Áurea (?) from Sanbra (an edible oil company), as well as Guimarães from Riga and the business leaders Papa Júnior and Abram Júnior, respectively President and Director of the São Paulo Business Federation, which provided staff from the National Service for Trade Apprenticeship (SENAC). 
In fact, the PIFAT/PAT ended up being principally run for the industrial sector, which in 1977 represented $76.2 \%$ of registered companies 27 . Benefiting workers and companies from this sector led to a contradiction with another program, the PRONAN II, which was set up at the same time in Brazil and aimed to promote food supplements for the low-income population. Dentist and INAN Director Mozart de Abreu e Lima (E16) was a member of the first PIFAT/PAT commission and emphasized the focus on this target population:

"A fund was set up to finance food for the industrial worker. Pay close attention: industrial! The worker with the best access, the most resources and the greatest presence on the political scene" (E16).

Whether it was coincidental or not, the PIFAT/PAT did meet one of the 1978 demands of the ABC Paulista strike movement (led by Luiz Inácio da Silva) to curb rises in the prices employers charged for meals 47. The industrial focus was so evident that when the Brazilian Association of Collective Meals (ABERC) was created in 1984, it was named the Brazilian Association of Industrial Meals 48.

\section{Alliances that legitimized the PIFAT/PAT and made it feasible}

Boianovsky's entrance to the Ministry of Labor was his first role within the bureaucratic field and, simultaneously, his first interaction with agents from major companies, from whom he obtained intellectual and material aid to structure the programme. Boianovsky was a novice in this space, and his inclusion constituted a change in his professional trajectory, occupying a new position and a new role, within a new space and interacting with unknown agents. Originally from the medical field, he brought habitus and dispositions from that space. Under these circumstances, it fell to Prieto to mediate both his inclusion in the high-level ministerial administration, appointing him as subsecretary for social promotion, and his coordination with agents from the economic field. According to Boianovsky, the minister requested to Checcia, then President of the ABAPe and Human Resources Director of Rhodia, welcome him, since the human resources staff were the program's initial interface 43 .

In May 1976, the French group Jacque Borel International began operating in Brazil under the name Ticket Restaurant. The agent in charge was Firmin António (António), a Portuguese-born Frenchman and an administrator with an ascendant social trajectory. Although António attributed his arrival in the country to chance, it happened to coincide with the launch of the PIFAT/PAT 49. The marrying of his company's economic interests with those of the program may be associated with the fact that, despite no visible active participation at the beginning of the genesis, the group not only began to dominate what would become the PIFAT/PAT space, but also became synonymous with the actual business mode: tickets (or vouchers, through meal agreements). It was the second company to be registered on the program.

The program's formulation was thus based on the meeting between the Boianovsky, Salomon and Silva trajectories, and on the coincidence of interests with agents and institutions from the economic field (Figure 1). It fell to Prieto to mediate the meeting between established trajectories that made the intervention feasible. One may therefore observe a relationship between agents and institutions that enabled mutual knowledge, recognition and legitimation (symbolic capital), made explicit in the honours conferred by ABAPe to Prieto (Medal of Merit), Boianovsky and Checcia (Personnel Manager of the Year).

It is thus evident that the PIFAT/PAT emerged from within the bureaucratic field, but interfaced with the economic field, notably in the sub-space dominated by agents linked to personnel management in major companies, mostly from industries in the state of São Paulo the richest state in the country). These agents had in common a high level of private administrative capital and activist capital, as well as trajectories for coordinating with the central power, particularly regarding workforce training (Table 4).

\section{Improvisations}

Since it was a product of social construction, the PIFAT/PAT did not arise out of any rational formulation, nor was it part of the Prieto administration's original agenda. Its drafting was not born out of a Ministry of Labor structure or framework that, due to PND II guidelines and the possibilities 
Types and amounts of capital and social trajectory of the different agents who participated in the Tax Incentive Program for Workers' Food (PIFAT/PAT) formulation.

\begin{tabular}{|c|c|c|c|c|c|c|}
\hline Agent & Political capital & $\begin{array}{c}\text { Bureaucratic } \\
\text { capital }\end{array}$ & Activist capital & $\begin{array}{c}\text { Private } \\
\text { administrative } \\
\text { capital }\end{array}$ & Cultural capital & Social trajectory \\
\hline Arnaldo Prieto & $\uparrow \uparrow \uparrow \uparrow$ & $\uparrow \uparrow \uparrow \uparrow$ & & & $\uparrow \uparrow \uparrow$ & Ascendant \\
\hline Luiz G. Ferreira & & $\uparrow \uparrow \uparrow$ & & $\uparrow \uparrow$ & $\uparrow \uparrow \uparrow$ & Ascendant \\
\hline David Boianosvsky & & $\uparrow \uparrow \uparrow$ & & $\uparrow \uparrow$ & $\uparrow \uparrow \uparrow$ & Ascendant \\
\hline Oswaldo Checcia & & $\uparrow$ & $\uparrow \uparrow \uparrow \uparrow$ & $\uparrow \uparrow \uparrow \uparrow$ & $\uparrow \uparrow \uparrow$ & Ascendant \\
\hline Antônio Guimarães & & & $\uparrow \uparrow$ & $\uparrow \uparrow \uparrow$ & $\uparrow \uparrow \uparrow$ & Ascendant \\
\hline Firmin António & & & & $\uparrow \uparrow \uparrow \uparrow$ & $\uparrow \uparrow \uparrow$ & Ascendant \\
\hline Eglacy Porto Silva & & $\uparrow \uparrow$ & & $\uparrow \uparrow$ & $\uparrow \uparrow \uparrow$ & Ascendant \\
\hline
\end{tabular}

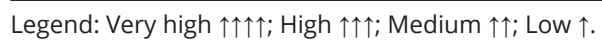

generated by the reformulation of the INAN, would have constructed a proposal for debate within the PRONAN II's own discussion spaces.

No reference to workers' food was found in the records of the $5^{\text {th }}$ National Health Conference 50. When the Ministry of Labor was separated from Social Security, there was no plan for a structure to signal a clear activity aimed at workers' food 51,52. Boianovsky himself was only formally integrated into the Ministry in March 1976, after PRONAN II was launched, since, given that the PIFAT/PAT implementation was uncertain and dependent on links with PRONAN II, he waited for it to be formalized before transferring from UnB to the Ministry of Labor. Before he was formally linked to the ministry, however, there is evidence that he and Salomon 53 prepared the first proposal presented to the minister. Subsequently, when he met Silva, he invited her to join his team.

Silva's employment status remained unstable for almost 20 years. The post of PAT manager was only created during the short administration of Minister Marcelo Pimentel (May 4, 1994 to January 1 st, 1995) 43. This shows that her continuity was secured by a complex network of interests, whose process of legitimacy was itself in its beginnings (Figure 1).

The direct participation of representatives from meal companies in the formulation of PIFAT/ PAT assured that Riga had priority and demonstrated the presence of private interests in the policy formulation.

"The three of us [Guimarães; Boianovsky and Ferreira] worked until dawn over three nights at Dr. David's residence. As a recompense for the work, and according to merit, RIGA received the no. 1 accreditation" (E5).

The influence of agents from this industry was so strong that even the $20 \%$ to be paid by the worker was based on the practices of the São Paulo business community 54 .

PIFAT/PAT was modelled according on the "Programme of Tax Incentives for Workforce Training”, which was in turn strongly influenced by agents from the Institute for Rational Labor Organization (IDORT), as Boianovsky explains:

"Since a tax incentive programme already existed (...) [the Minister] introduced me to (...) Ferreira, and he gave me some tips about how it worked. Therefore, I thought we could adapt it to food. We copied a series of models from that law, including company accreditation" 43.

For their part, successive measures in the tax incentive legislation coincided with disputes between the program's beneficiaries and the government's financial sector, as businesses sought to maximize tax benefits and the Federal Revenue Department sought to restrict them. If PRONAN II envisaged the "granting of financing and incentives for businesses and civil institutions for employers and employees" 55 the Law only dealt with incentives, establishing the "deduction from taxable income...", fixing the limit at $5 \%$ of taxable income, cumulatively $10 \%$ with the training program, and allowed that expenditure on food was not included "as a contribution to the salary proportion paid in kind", resulting in its exemption from payroll social security contributions 56 . The Decree included a new benefit, allowing spending 
Figure 1

Relationships between agents and institutions prior to the creation of the Tax Incentive Program for Workers' Food (PIFAT/PAT).

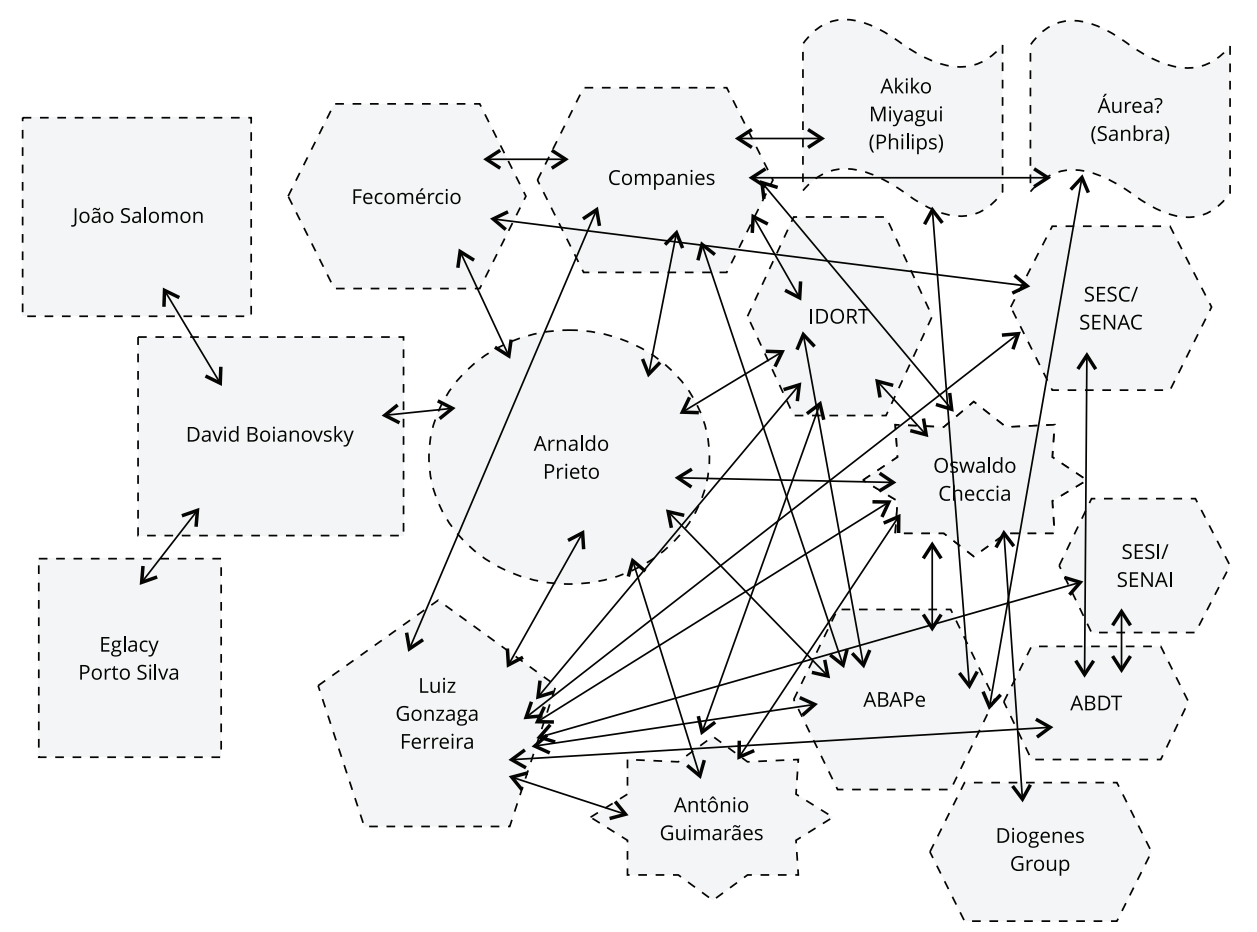

Agents "foreign" to the economic field prior to PIFAT/PAT emergence
Agents from the economic field

ABAPe: Brazilian Association of Personnel Management; ABDT: Brazilian Association of Training and Development; Fecomércio: São Paulo State Federation of Trade in Goods, Services and Tourism; IDORT: Institute for Rational Labor Organization; SENAC: National Service for Trade Apprenticeship; SENAI: National Service for Industrial Apprenticeship; SESC: Brazilian Trade Social Services; SESI: Brazilian Industrial Social Services.

on food to be classified as "Operational Spending", which represented an additional advantage of up to $34 \%$ on such spending, without any limit. It further stated that the worker could pay up to $20 \%$ of the cost of the meal. A 1977 Ministerial Order established that for the 5\% deduction there should be a maximum value per meal, with the worker paying $20 \% 55$. Thus, what had previously been a possibility (a discount of up to 20\%) became a fixed amount. 


\section{Conclusion}

The dynamics within the PIFAT/PAT space kept it away from the health sphere and revealed the dominance of the program's tax incentive nature, more closely related to interests from the economic field. Although it was formally part of the PRONAN II, the program aimed at food supplements for the low income population, and that, on some level, came under the jurisdiction of INAN and the Institute for Applied Economic Research (IPEA), a Ministry of Planning body, PIFAT/PAT was developed within the Ministry of Labor, with relative autonomy from other bodies. Not only we did not find any record of INAN or IPEA agents participating in its formulation, our analysis of the legislation also enabled us to identify that modifications to each norm were introduced and it ensured total Ministry of Labor autonomy over its management. Although the Ministry of Labor Law should have "linked" INAN to the approval of the worker food program, according to the Decree, decisions about each program "fell" to the Minister of Labor. In 1976, the PIFAT/PAT Commission had two representatives per ministry - Labor; Finance and INAN/Health - but in 1987 the Ministry of Labor had three representatives, Finance two and INAN only one 55 . In other words, the process led to the progressive domination of the logics of economics and the reproduction of the workforce within the program's management.

PIFAT/PAT creation represented the structuring of a social space with interests predominantly from an emerging meal market, from businesses seeking to lower production costs, and agents from Human Resources management and from the State, aimed at fulfilling the PND II. This space was shaped by the strengthening of a billion dollar sector in the domestic economy, which very probably ensured its longevity. The presence of agents from the medical and nutrition space was essential in providing the semblance of technical rationality, although this was secondary within the program, concealing its fundamentally fiscal nature even from those who studied it and who, due to the effect of genesis amnesia, ignored it or did not properly ascribe its true nature.

The facts present in this genesis, and later forgotten, may help to explain PIFAT/PAT's distance from the health sector, as well as the low participation of agents from the Ministry of Health in its running. It may also help to explain an apparent contradiction: ministerial orders related to PIFAT/PAT nutritional parameters were also signed by the Ministry of Health, providing evidence of an official link with the Programme, but the National Policy of Food and Nutrition 57 makes no mention of it.

Furthermore, the coordination that led to the PIFAT/PAT represented the Ministry of Labor's resumption of the issue of worker food, following the cancellation of the Social Security Food Service (SAPS), gradually taking it away from the Ministry of Health, despite officially being part of PRONAN II. This is one possible reason why this public intervention, which financed the daily meals of millions of adults, does not appear on the health promotion policy agenda, even though it is related to workers' health and/or to the promotion of healthy and adequate food. Thus, what seem to be contradictory are, in fact, the results of the dynamics within a specific social space, whose historical and social construction has been partially revealed here.

Pierre Bourdieu's social world theory has given us an approach that went beyond historiography and the reproduction of official points of view, to identify a particular social dynamic within a unique social space, providing evidence of the objective conditions for the emergence of a social policy such as the PIFAT/PAT. It supported our understanding of both its longevity and the results it has achieved up to the present day. 


\section{Contributors}

J. Costa-Souza contributed to the study design, data collection and analysis, writing, and revision of the paper. L. M. Vieira-da-Silva contributed to the study design, data analysis, writing, and revision of the paper. P. Pinell contributed to the study design, data analysis, and revision of the paper.

\section{Acknowledgments}

We thank the interviewees and everyone who made their personal collections available for this research.

\section{References}

1. Atkinson JA, Page A, Wells R, Milat A, Wilson A. A modelling tool for policy analysis to support the design of efficient and effective policy responses for complex public health problems. Implement Sci 2015; 10:26.

2. Coleman JS. The role of social policy research in society and in sociology. Am Sociol 1987; 18:127-33.

3. Collins T. Health policy analysis: a simple tool for policy makers. Public Health 2005; 119:192-6.

4. Embrett MG, Randall GE. Social determinants of health and health equity policy research: exploring the use, misuse, and nonuse of policy analysis theory. Soc Sci Med 2014; 108:147-55.
5. Jerneck A, Olsson L. Breaking out of sustainability impasses: how to apply frame analysis, reframing and transition theory to global health challenges. Environ Innov Soc Transit 2011; 1:255-71.

6. Höfling EM. Estado e políticas (públicas) sociais. Cad CEDES 2001; 21:30-41.

7. Fernandez RM, Gould RV. A dilemma of state power: brokerage and influence in the national-health policy domain. Am J Sociol 1994; 99:1455-91.

8. Pires MRGM, Demo P. Políticas de saúde e crise do Estado de Bem-Estar: repercussões e possibilidades para o Sistema Único de Saúde. Saúde Soc 2006; 15:56-71. 
9. Porter S. Capitalism, the state and health care in the age of austerity: a Marxist analysis. Nurs Philos 2013; 14:5-16.

10. Wacquant LJD. O legado sociológico de Pierre Bourdieu: duas dimensões e uma nota pessoal. Revista de Sociologia e Política 2002; 19:95-110

11. Vieira-da-Silva LM, Dussault G. Santé, espace social et pratiques. Ruptures 1999; 6:192-208.

12. Carpiano RM. Toward a neighborhood resource-based theory of social capital for health: can Bourdieu and sociology help? Soc Sci Med 2006; 62:165-75.

13. Stephens C. Social capital in its place: using social theory to understand social capital and inequalities in health. Soc Sci Med 2008; 66:1174-84.

14. Lessard C, Contandriopoulos A-P, Beaulieu M-D. The role (or not) of economic evaluation at the micro level: can Bourdieu's theory provide a way forward for clinical decisionmaking? Soc Sci Med 2010; 70:1948-56.

15. Albert M, Laberge S, Hodges BD, Regehr G, Lingard L. Biomedical scientists' perception of the social sciences in health research. Soc Sci Med 2008; 66:2520-31.

16. McDonald R. Market reforms in English primary medical care: medicine, habitus and the public sphere. Sociol Health Illn 2009; 31:65972.

17. Lenoir R. L'invention du "troisième âge". Actes Rech Sci Soc 1979; 26:57-82.

18. Nicolas F. La (les) trajectoire(s) du changement. Actes Rech Sci Soc 2014/2015; (205):42-57.

19. Pinell P. The fight against cancer: France 1890-1940. London/New York: Routledge Studies in the History of Science, Technology and Medicine; 2002.

20. Pinell P. Análise sociológica das políticas de saúde. Rio de Janeiro: Editora Fiocruz; 2011.

21. Bourdieu P. Sur l'État - cours de collège de france: 1989-1992. Paris: Raisons d'Agir/Seuil; 2012.

22. Araujo MDN, Costa-Souza J, Trad LAB. Worker diet in Brazil: a review of Brazilian scholarship on the topic. Hist Ciênc Saúde-Manguinhos 2010; 17:975-92.

23. Moura JB. Avaliação do programa de alimentação do trabalhador, no estado de Pernambuco, Brasil. Rev Saúde Pública 1986; 20:115-28.

24. Sarno F, Bandoni DH, Jaime PC. Excesso de peso e hipertensão arterial em trabalhadores de empresas beneficiadas pelo Programa de Alimentação do Trabalhador (PAT). Rev Bras Epidemiol 2008; 11:453-62.
25. Ministério do Trabalho e Emprego. Relatório total PAT: relação de empresas beneficiárias ativas no PAT. http://pat.mte.gov.br/relato rios2008/relatorioconsultatotalpat.asp (accessed on 15/Nov/2012).

26. Da Silva MHO. Programa de Alimentação do Trabalhador - PAT: estudo do desempenho e evolução de uma politica social [Doctoral Dissertation]. Rio de Janeiro: Escola Nacional de Saúde Pública, Fundação Oswaldo Cruz; 1998.

27. Colares LGT. Evolução e perspectivas do programa de alimentação do trabalhador no contexto político brasileiro. Nutrire Rev Soc Bras Aliment Nutr 2005; 29:141-58.

28. Veloso IS, Santana VS, Oliveira NF. The Brazilian Workers' Food Program and its impact on weight gain and overweight. Rev Saúde Pública 2007; 41:769-76.

29. Mazzon JA. Programa de alimentação do trabalhador. 30 anos de contribuições ao desenvolvimento do Brasil. São Paulo: Fundação Instituto de Administração; 2006.

30. Silva NF. Auxílio alimentação: do papel à cédula, uma nova estratégia de utilização. Uma proposta de restaurante em Universidade pública. Niterói: Universidade Federal Fluminense; 2002.

31. Silva AC. De Vargas a Itamar: políticas e programas de alimentação e nutrição. Estud Av 1995; 9:87-107.

32. Bandoni DH, Brasil BG, Jaime PC. Programa de Alimentação do Trabalhador: representações sociais de gestores locais. Rev Saúde Pública 2006; 40:837-42.

33. Magalhães SG. Comissão Tripartite do Programa de Alimentação do Trabalhador - CTPAT: processo decisório. Um estudo exploratório - 1997/2001 [Masters Thesis]. Rio de Janeiro: Escola Nacional de Saúde Pública, Fundação Oswaldo Cruz; 2002.

34. Viana SV. Indústria moderna e padrão alimentar: o espaço do trabalho, do consumo e da saúde [Doctoral Dissertation]. Salvador: Instituto de Saúde Coletiva, Universidade Federal da Bahia; 2000.

35. Bourdieu P. Meditações pascalianas. Rio de Janeiro: Bertrand Brasil; 2007.

36. Bourdieu P. A distinção: crítica social do julgamento. São Paulo: Edusp/Porto Alegre: Zouk; 2007. 
37. Bourdieu P. Les trois états du capital culturel. Actes Rech Sci Soc 1979; 30:3-6.

38. Bourdieu P. Le capital social. Actes Rech Sci Soc 1980; 31:2-3.

39. Matonti F, Poupeau F. Le capital militant. Essai de définition. Actes Rech Sci Soc 2004/2005; (155):4-11.

40. Coimbra M. Dois modelos de intervenção nutricional no Brasil, PNS e PROAB. In: Castro $\mathrm{CM}$, Coimbra M, editores. O problema alimentar no Brasil. São Paulo: Editora da Unicamp/Almed; 1985. p. 71-149.

41. David Boianovsky vai presidir o INAN. Jornal de Brasília 1974; 6 jun.

42. Arruda BKG. Alimentação e nutrição no Brasil: percepções do passado para transformação do presente Recife. Recife: Instituto de Medicina Integral Professor Fernando Figueira; 2008.

43. MAIS comida, menos PAT. Cozinha Industrial 1994; 6:12-25.

44. Brasil. II Plano Nacional de Desenvolvimento (1975-1979). Anexo da Lei no 6.151, de 04 de dezembro de 1974. Brasília: Presidência da República; 1974.

45. Grupo Diógenes. Histórico 2012. http://www. grupodiogenesrh.com.br/conteudo/page.as px?ID=2 (accessed em 15/Aug/2012).

46. Brasil. Decreto-Lei no 1.238, de 02 de maio de 1939. Dispõe sobre a instalação de refeitórios e a criação de cursos de aperfeiçoamento profissional para trabalhadores. Diário Oficial da União 1939; 6 mai.

47. Sindicato dos Trabalhadores nas Indústrias Metalúrgicas, Mecânicas e de Material Elétrico de São Bernardo do Campo e Diadema. Campanhas salariais: 1978. http://www.abcdeluta. org.br/textos.asp?id_CON=45 (accessed on 29/Dec/2012).

48. ABERC completa 25 anos. ABERC Notícias 2009; ano XIX, n. 107.

49. Blecher N. O incrível Firmin! Exame 2000; 26 jan.
50. Ministério da Saúde. Anais da Conferência Nacional de Saúde. http://portal.saude.gov.br/ portal/arquivos/pdf/5_CNS_anais.pdf (accessed on 17/Jan/2013).

51. Brasil. Lei no 6.036, de 1o de maio de 1974 . Dispõe sobre a criação, na Presidência da República, do Conselho de Desenvolvimento Econômico e da Secretaria de Planejamento, sobre o desdobramento do Ministério do Trabalho e Previdência Social e dá outras providências. Diário Oficial da União 1974; 2 mai.

52. Brasil. Decreto no 76.386 , de 02 de outubro de 1975. Dispõe sobre a Estrutura Básica do Ministério do Trabalho e dá outras providências. Diário Oficial da União 1975; 3 out.

53. Araújo MS, Costa THM, Sávio KEO, Schimitz BAS. Programa de Alimentação do Trabalhador: uma abordagem reflexiva. Brasília Médica 2004; 41:60-5.

54. Instituto de Organização Racional do Trabalho; Associação Brasileira de Administração de Pessoal. Seminário de incentivo fiscal à alimentação do trabalhador. São Paulo: Instituto de Organização Racional do Trabalho/Associação Brasileira de Administração de Pessoal; 1977.

55. Ministério do Trabalho. Tudo sobre o programa de alimentação do trabalhador. Brasília: Ministério do Trabalho; 1987.

56. Brasil. Decreto no 77.116 , de 06 de fevereiro de 1976. Estabelece diretrizes para a ação do Governo na área de Alimentação e Nutrição, aprova o Programa Nacional de Alimentação e Nutrição - PRONAN e dá outras providências. Diário Oficial da União 1976; 6 fev.

57. Ministério da Saúde. Política Nacional de Alimentação e Nutrição. Brasília: Ministério da Saúde; 2012.

58. Vieira-da-Silva LM, Pinell P. The genesis of collective health in Brazil. Sociol Health Illn 2014; 36:432-46.

59. Chiavenato I. Introdução à teoria geral da administração. 7a Ed. Rio de Janeiro: Elsevier; 2003. 


\section{Resumo}

Análises de politicas que partem das concepções clássicas ou estruturalistas do Estado, embora importantes, apresentam algumas limitações na explicação dos processos relacionados com a sua formulação, implementação e resultados. A sociologia Bourdieusiana, ao articular a análise das dimensões objetivas e subjetivas das práticas sociais, pode contribuir para a compreensão desses fenômenos. Este artigo traz evidências empíricas a esse respeito ao analisar a sociogênese de uma politica brasileira que atende atualmente a 18 milhões de trabalhadores e que foi instituída pelo Estado em 1976, consubstanciada no Programa de Incentivo Fiscal da Alimentação do Trabalhador (PIFAT/PAT). O trabalho articulou a análise da trajetória dos agentes sociais envolvidos com a sua formulação e o estudo das condições históricas de possibilidade de sua emergência. Embora a literatura a trate como um programa de alimentação do trabalhador (PAT), o presente estudo revelou que, de fato, ela representou um novo modelo de subsídio financeiro às empresas que ofereciam alimentação aos seus empregados, potencializando o mercado de refeições coletivas. Foi ainda constatado que o programa emergiu no interior do campo burocrático, mas em articulação com agentes do campo econômico. Constituiu-se como espaço social específico, em que as questões relacionadas à alimentação se mostraram secundárias, mas úteis na ocultação da face antes explícita em sua gênese: sua natureza essencialmente tributária.

Politica de Saúde do Trabalhador; Programas de Nutrição; Serviços de Alimentação; Sociologia

\section{Resumen}

Análisis de politicas que parten de concepciones clásicas o estructuralistas del Estado que, pese a que son importantes, presentan algunas limitaciones en la explicación de los procesos relacionados con su formulación, implementación y resultados. La sociología Bourdieusiana, al vincular el análisis de las dimensiones objetivas y subjetivas de las prácticas sociales, puede contribuir a la comprensión de estos fenómenos. Este artículo presenta evidencias empíricas a este respecto, al analizar la sociogénesis de una política brasileña que atiende actualmente a 18 millones de trabajadores, y que fue instituida por el Estado en 1976, consustancial al Programa de Incentivo Fiscal de la Alimentación del Trabajador (PIFAT/PAT). El estudio trata tanto sobre el análisis de la trayectoria de los agentes sociales implicados en su formulación, como sobre el estudio de las condiciones históricas acerca de las posibilidades para su aparición. A pesar de que la literatura lo considere un programa de alimentación del trabajador (PAT), el presente estudio reveló que, de hecho, representó un nuevo modelo de subsidio financiero para las empresas que ofrecian alimentación a sus empleados, potenciando el mercado de comidas colectivas. Se constató incluso que el programa surgió dentro del ámbito burocrático, pero en coordinación con agentes del área económica. Se constituyó como un espacio social específico, donde las cuestiones relacionadas con la alimentación se mostraron secundarias, pero útiles para el ocultar un aspecto antes explícito en su génesis: su naturaleza eminentemente tributaria.

Politica de Salud Ocupacional; Programas de Nutrición; Servicios de Alimentación; Sociología

Submitted on 10/Aug/2016

Final version resubmitted on 13/Feb/2017

Approved on 24/Apr/2017 